International Journal of Environment, Agriculture and Biotechnology
Vol-6, Issue-3; May-Jun, 2021
J Journal Home Page Available: https://ijeab.com/
Journal DOI: $10.22161 /$ ijeab

Article

Peer-Reviewed Journal

\title{
Effect of scarification methods on different forest seeds
}

\author{
R. Priyadharshini ${ }^{1}$, Dr. K. Lekha ${ }^{2}$
}

M. Sc. Botany, Department of Botany, PSG college of arts and science, Coimbatore, Tamilnadu, India. Assistant professor, Department of Botany, PSG college of arts and science, Coimbatore, Tamilnadu, India.

Received: 17 May 2021; Received in revised form: 11 Jun 2021; Accepted: 21 Jun 2021; Available online: 30 Jun 2021 (C)2021 The Author(s). Published by Infogain Publication. This is an open access article under the CC BY license (https://creativecommons.org/licenses/by/4.0/).

Abstract-A study describes various pre-sowing treatment attributed to the seed germination and seedling growth of seeds such as Terminalia chebula (Gaertn.) Retz., Terminalia bellirica (Gaertn.) Roxb., Pongamia pinnata (L.) Pierre, Santalum album L., Tamarindus indica L by different methods of scarification to determine the germination percentage, germination rate and germination period of seeds. These seeds were collected from IFGTB, Coimbatore in the month of January 2021 respectively. The effects of depulping and soaking period on seed germination and seedling growth performance were explored. The fastest seed germination and highest germination percentage was observed in acid scarification(T4) followed by coconutwater treatment(T3) and rice water treatment(T2) and delayed germination with lowest percentage was observed in mechanical scarification(T4). Growth parameters including shoot length and root length were also maximum and significantly higher in the same treatment compared to others. Considering the practicability of the nursery raising technique for the species, the best treatment option obtained in this study was soaking the five types of seeds in concentrated acid such as $10 \%$ of con sulphuric acid for one hour. Since, the acid treatment for a particular period of time is easily applicable and cost effective, the treatment may be recommended for large scale seedling productions in the nurseries.

Keywords- Pre-sowing treatment, Germination percentage, germination rate, germination period, depulping and soaking.

\section{INTRODUCTION}

Germination is the process by which an organism grows from a seed or similar structure. The term is applied to the sprouting of a seedling from a seed of an angiosperm or gymnosperm, the growth of a sporeling from a spore, such as the spores of fungi, ferns, bacteria, and the growth of the pollen tube from the pollen grain of a seed plant. Seed germination depends on both internal and external conditions. The most important factors include right temperature, water, oxygen, or air and sometimes light or darkness. Various plants require different variables for successful seed germination. Often this depends on the individual seed variety and is closely linked to the ecological conditions of a plant's natural habitat. For some seeds, their future germination response is affected by environmental conditions during seed formation; most often these responses are types of seed dormancy. The seed of many species are often impervious to water and gases, thus preventing on delaying germination. Any process designed to make the seed coat more permeable to water and gases, thus help to germination of seed is called as scarification. Scarification is a process that weakening, opening or otherwise altering the seed coat to developing the germination. Scarification is often done by mechanical, rice water, coconut water and acid treatment. The seed of plants which are otherwise difficult to grow from seed may be made viable through scarification. In horticulture, scarification is often used to facilitate the controlled and uniform germination of seed.

Terminalia chebula (Gaertn.) Retz. is an important medicinal tree species in the Asian countries. It is routinely used as traditional medicine by tribes of tamilnadu to cure several ailments such as fever, cough, diarrhea, gastroenteritis, skin diseases, candidiasis, urinary tract 
infection and wound infections. Unripe fruits are useful medicine for diarrhea, dysentery an leprosy(Singh, et al., 1965). Dry fruits posses a potential broad spectrum of antihelminthic, antimicrobial activity against both Grampositive and Gram-negative bacteria. Aqueous extract of $T$. chebula fruits exhibits antifungal activity against a number of dermatophytes and yeasts (Dutta, et al., 1998). It possesses antiviral activity against Herpes Simplex Virus type-1 (HSV-1), Human Immune Deficiency Virus-1 (HIV-1) and cytomegalovirus (Yuka, et al., 1996). Seventy percent methanol extract and phenolic compound of $T$. chebula fruits decrease cancer cell viability, cell proliferation, and induced cell death in a dose dependent manner (Saleem, et al., 2002). However, the poor germination capacity (Shankar, 2001) and longer germination period (up to 2-3 months) are the major constraints of raising seedling and establishing plantation of the species (Luna 1996).

Terminalia bellirica (Gaertn.) Roxb. (Combretaceae) is an ecologically and medicinally important deciduous canopy tree species having wide distribution throughout india, but with limited distribution and density in evergreen forests of the Western Ghats and is often associated with teak. Seed is edible; exocarp is one of the important components of a medicine commonly known as "Triphala churan" (used in bronchitis, cough problems, indyspepsia, constipation, impurity of blood and stomach problem) (CSIR 1985). The fruit of T.bellirica contain very high level of phenolic compounds (TPC) (Bajpai et al., 2005) including Glucoside (bellaricanin), Gallo-tannic acid, resins, oil, Ellargic acid, gallic acid, lignans 7 hydroxy 3'4' flavones and anolignan B, tannins, ethyl gallate, phenyllemblin, mannitol, glucose, fructose and rhamnose. The delay and irregularity in germination of seeds is believed to be due to the hard seed coat and thick fleshy pericarp of the fruits of the species (Shivanna et al., 2001). Seed germination may be reduced by the presence of impermeable seed coats that restricts the availability of water, which can penetrate into seeds at their optimum concentration (Kumar et al., 2015a,b).Seeds were given a pretreatment to overcome the problem of hard seed-coat. They were soaked in boiled water for a period of $24 \mathrm{~h}$ (water was boiled, seeds were dipped into it and then the vessel was removed from the hot plate and kept at room temperature for $24 \mathrm{~h}$ ) (Todaria \& Negi 1992). Indian sandalwood (Santalum album L.) is a commercially and culturally important plant species, known for its fragrant heartwood and oil. The sandalwood oil, known as santalol is highly demanded by the perfume industry due to its sweet fragnance, persistent aroma and the fixative property (Jain et al., 2003).
Pongamia pinnata (L.) Pierre is one of the plant species, which yield oil as a source of energy in the form of biodiesel, with high oil recovery and the quality of oil (Shrinivasa, 2001). Pongamia pinnata (L.) Pierre also called as Derriss indica(Lam.) Bennet is a tree species belonging to the family Fabaceae. This species is commonly known as Pongam or karanj. The seed oil is used as a lubricant, water paint binder, pesticide, in soap making and tanning industries. The oil is used for the treatment of rheumatism and scabies. All parts of the plant have been used as crude drug for the treatment of tumors, piles, skin diseases, wounds and ulcers (Tanaka et al., 1992). The press cake is used as poultry feed and also as organic fertilizer. It controls soil erosion and binds sand dumes (Wani, et al., 2005). The Pongamia pinnata seeds contain about $40 \%$ oil, which can be converted to biodiesel by transesterification method (Meher et al., 2006). Seed germination, one of the most important phases in the life cycle of a plant, is highly responsive to existing environment (Kuriakose et al., 2008). Water stress is one of the abiotic stresses, which affect seed germination, delaying its beginning or decreasing the final germinability (Silva et al., 2005). Its participation is crucial in the enzymatic reactions, solubilisation and transportation of metabolites, as well as reagent in the hydrolysis of proteins, carbohydrates and lipids in the storage tissues of the seed (Mayer et al., 1989) According to Hadas(Hadas, et al., 1976), the critical soil water potential for seed germination, is typical for each plant species. Therefore, solutions with different osmotic potentials have been used in several studies in order to establish gradient of water stress.

Tamarindus indica L. is a leguminous tree in the family fabaceae native to tropical Africa. T. indica is used as traditional medicine in India, Pakistan, Bangladesh, Nigeria, and most of the tropical countries. Temperature requirements for germination vary with species. Many seeds germinate at temperatures slightly above $60-75^{\circ} \mathrm{F}$ $\left(16-24^{\circ} \mathrm{C}\right)$, though there are certain seeds that require exposure to cold temperature (vernalization) in order to break dormancy, for example, Helleborus niger of the family Ranunculaceae (Gama-Arachchige,2013). (Nwoboshi,1982) stated that low temperature prolongs the length of seed viability; hence creating artificially low temperatures has been found useful in seed storage. High temperatures affect germination of seeds by influencing the water holding capacity of the soil which, thus, determines to a large extent the survival of germinating seeds. 


\section{MATERIALS AND METHOD}

The seeds of Terminalia chebula (Gaertn.) Retz., Terminalia bellirica (Gaertn.) Roxb., Pongamia pinnata (L.) Pierre, Santalum album L., Tamarindus indica L, were collected from IFGTB, Coimbatore in the month of January 2021. Scarification is a process of weakening, opening or otherwise altering the seed coat to enhance the germination. Scarification is often done by mechanical, rice water, coconut water and acid treatment. $\mathrm{T}$ denotes test has been listed below.

T1-Mechanical scarification

T2-Ricewater treatment

T3-Coconutwater treatment

T4-Acid treatment

Mechanical scarification (T1): In mechanical scarification, factors for breaking hard seed coat was applied in this study includes emery sheet, nailed hammer. Nailed hammer was used to breaking the seed coat and emery sheet used to scarped the testa of seed. In this five types of seeds ( Terminalia chebula (Gaertn.) Retz., Terminalia bellirica (Gaertn.) Roxb., Pongamia pinnata (L.) Pierre, Santalum album L., Tamarindus indica L.) were scarified using nail hammer.

Ricewater treatment (T2): Scarification of seeds in rice water, it contains triglycerides and lipids each makeup 10 percent of the rice water composition, while starch is present at 9 percent. Carbohydrates, inositol, phytic acid, and inorganic substances components helps to scarify the seed coat are other components in rice water. The five types of seeds were soaked in rice water overnight, to promote the germination of seed.

Coconutwater treatment (T3): Scarification of seeds in coconut water, it contains physicochemical properties such as volume of water, titratable acidity, $\mathrm{pH}$, Turbidity, sugar content such as fructose, glucose, sucrose, mineral content such as potassium, sodium, magnesium, calcium, iron, protein, total phenolic content. These properties helps to scarify the seed coat. The five types of seeds were soaked in coconut water overnight, promote the germination of seed.

Acid treatment (T4): In this five types of seeds (Terminalia chebula (Gaertn.) Retz., Terminalia bellirica (Gaertn.) Roxb., Pongamia pinnata (L.) Pierre, Santalum album L., Tamarindus indica L.) can be soaked in concentrated acid such as $10 \%$ of con sulphuric acid. This can be soaked for one hour.

Pre-sowing treatment and growing media: The extracted seeds were cleaned and thoroughly hand mixed to improve the homogeneity during the sampling. Seeds were subjected to pre-sowing treatments. The pre-treated seeds were sown in polythene bags containing the rooting medium soil mixed with decomposed cow-dung, sand and vermicompost contains water-soluble nutrients and is an excellent, nutrient-rich organic fertilizer and soil conditioner, The soil was moderately coarse to fine textured sandy loams with $\mathrm{pH}$ 4.5. Before filling with the prepared soil mixture, few holes were made in the polybag by punching to facilitate aeration and proper drainage. Randomized complete block design was adopted for the study with five types of seeds for each treatment. Thus each treatment consisted of 5 seeds and a total of 20 seeds were subjected to 4 different pre-sowing treatments.

Seed sowing and aftercare: Only one seed was sown in each polybag filled with growing media directly. Seeds were dibbed to $0.5 \mathrm{~cm}$ beneath the soil surface by pressing them with thumb and covered with thin layer of soil. After sowing the seeds, protective measures were adopted against the hot sun, intensive rains, birds, rodents and pests. Proper care was taken since the sowing of seeds till the harvesting of seedlings for assessment. Watering and weeding were done regularly to obtain maximum growth of seedlings. Loosening of topsoil was also done whenever necessary to prevent the growth of green mold on the soil surface.

Data recording and growth assessment: The effects of pre-sowing treatments on germination of seeds and seedling growth were explored periodically through counting germinated seeds and assessing initial growth performance of seedlings. Germination phase like imbibition period was determined by counting the number of days required for the commencement of germination from the day of sowing and germination period was the number of days required for completion of germination from sowing the seeds.

For assessing the growth performance, all seedlings were measured for total length (root length, shoot length). Five seedlings from each replication treatment were randomly uprooted and measured for total length. The seedlings were then separated into root and shoot were also recorded to assess the growth performance of the seedlings.

Assesment variables:

Germination percentage: Seed germination percentage was calculated using the following formula: Germination percentage $\%=$ Number of seeds germinated / total number of seeds sown $\times 100$. 


\section{RESULTS AND DISCUSSION}

\section{Terminalia bellirica (Gaertn.) Roxb.}

Germination period: Seeds of $T$. bellirica (Gaertn.) Roxb. started to germinate 21 days after sowing and continued up to 65 days. Different pre-sowing treatments significantly affected the germination period for the species. The fastest seed germination (least imbibition period; 21 days) was observed in acid scarification(T4) (using $10 \%$ of con.H2SO4) followed by rice water treatment(T2) in 27 days, coconutwater treatment(T3)
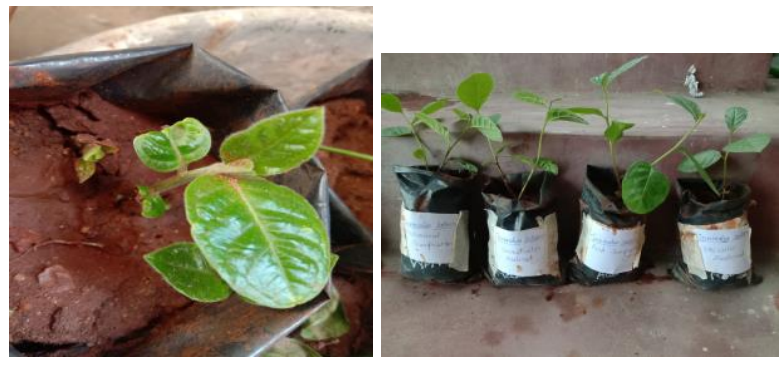

\section{Terminalia chebula (Gaertn.) Retz.}

Germination period: Seeds of T.chebula (Gaertn.) Retz. started to germinate 25 days after sowing and continued up to 70 days. Different pre-sowing treatments significantly affected the germination period for the species. The fastest seed germination (least imbibition period; 25 days) was observed in acid scarification(T4) (using 10\% of con.H2SO4) followed by rice water treatment(T2) in 30 days, coconut water treatment(T3) in 33 days and in 25 days and delayed (highest imbibition period) was observed in mechanical scarification(T1) (nail punched method). However, the fastest completion of seed germination (35 days) was noticed in acid scarification(T4) and slowest completion (65 days) was in mechanical scarification(T1). The germination percentage of the seeds, shoot length and root length has been listed in table.
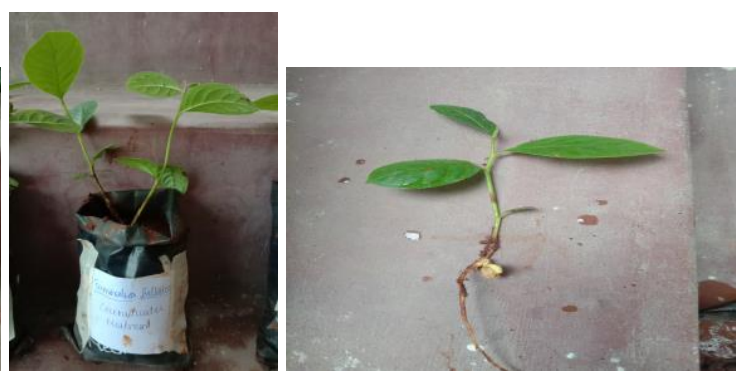

delayed (highest imbibition period, 70 days) was observed in mechanical scarification(T1) (nail punched method). However, the fastest completion of seed germination (40 days) was noticed in acid scarification(T4) and slowest completion (70 days) was in mechanical scarification(T1). The germination percentage of the seeds, shoot length and root length has been listed in the table.
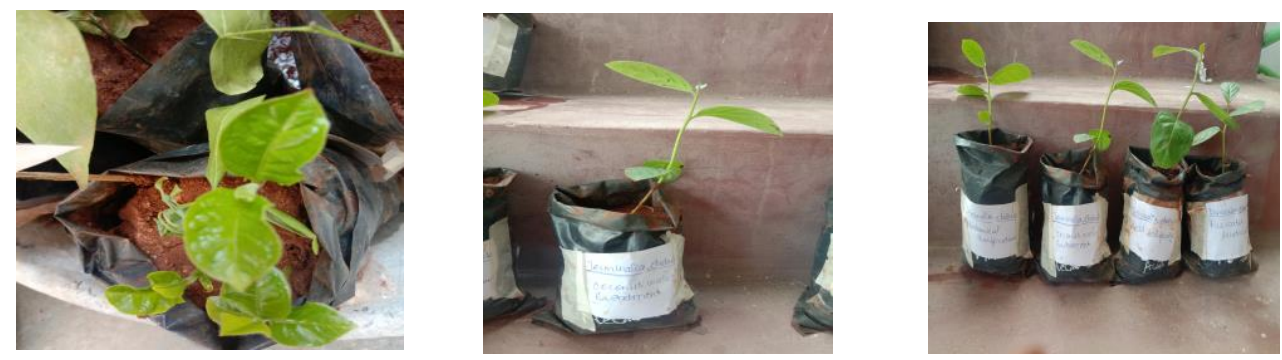

\section{Tamarindus indica $\mathbf{L}$.}

Germination period: Seeds of T.indica L. started to germinate 8 days after sowing and continued up to 51 days. Different pre-sowing treatments significantly affected the germination period for the species. The fastest seed germination (least imbibition period; 8 days) was observed in acid scarification(T4) (using $10 \%$ of con.H2SO4) followed by rice water treatment(T2) in 12 days, coconut water treatment(T3) in 19 days and delayed (highest imbibition period, 25 days) was observed in mechanical scarification(T1) (nail punched method). However, the fastest completion of seed germination (30 days) was noticed in acid scarification(T4) and slowest completion (51 days) was in mechanical scarification(T1). The germination percentage of the seeds, shoot length and root length has been listed in the table. 

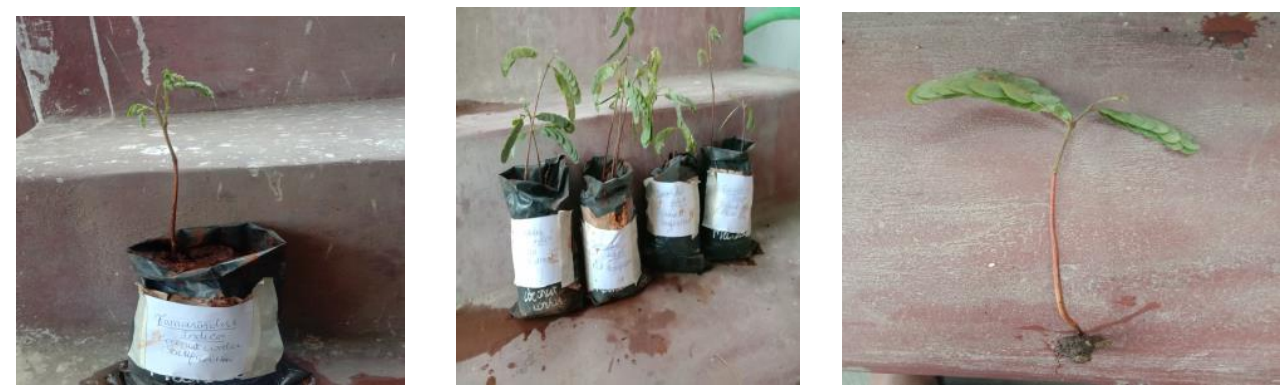

\section{Santalum album $\mathrm{L}$.}

Germination period: Seeds of Santalum album L. started to germinate 15 days after sowing and continued up to 60 days. Different pre-sowing treatments significantly affected the germination period for the species. The fastest seed germination (least imbibition period; 15 days) was observed in acid scarification(T4) (using 10\% of con.H2SO4) followed by rice water treatment(T2) in 20 days then coconut water treatment(T3) in 22 days and delayed (highest imbibition period, 26 days) was observed in mechanical scarification(T1) (nail punched method). However, the fastest completion of seed germination (35 days) was noticed in acid scarification(T4) and slowest completion (60 days) was in mechanical scarification(T1). The germination percentage of the seeds, shoot length and root length has been listed in the table.
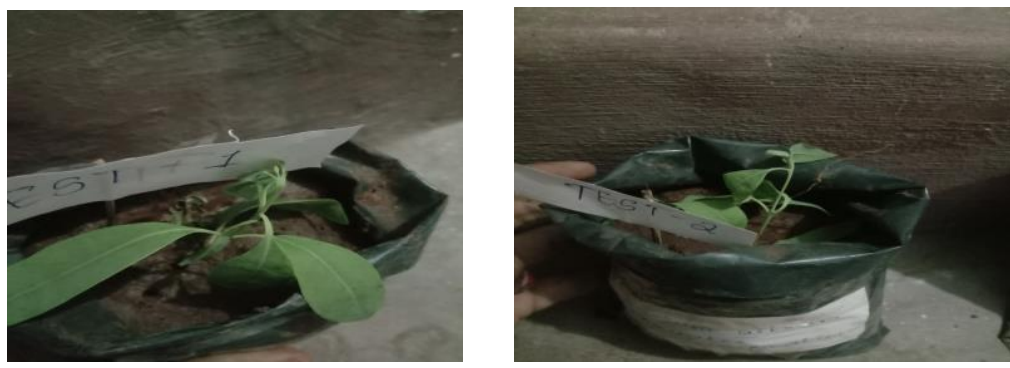

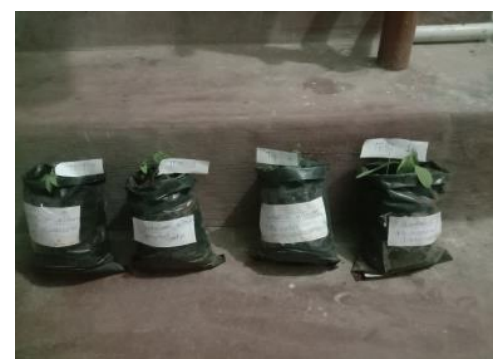

in 25 days and delayed (highest imbibition period, 30 days) was observed in mechanical scarification(T1) (nail punched method). However, the fastest completion of seed germination (32 days) was noticed in acid scarification(T4) and slowest completion (56 days) was in mechanical scarification(T1). The germination percentage of the seeds, shoot and root length has been listed in the table. (using $10 \%$ of con.H2SO4) followed by rice water treatment(T2) in 20 days, coconut water treatment(T3)
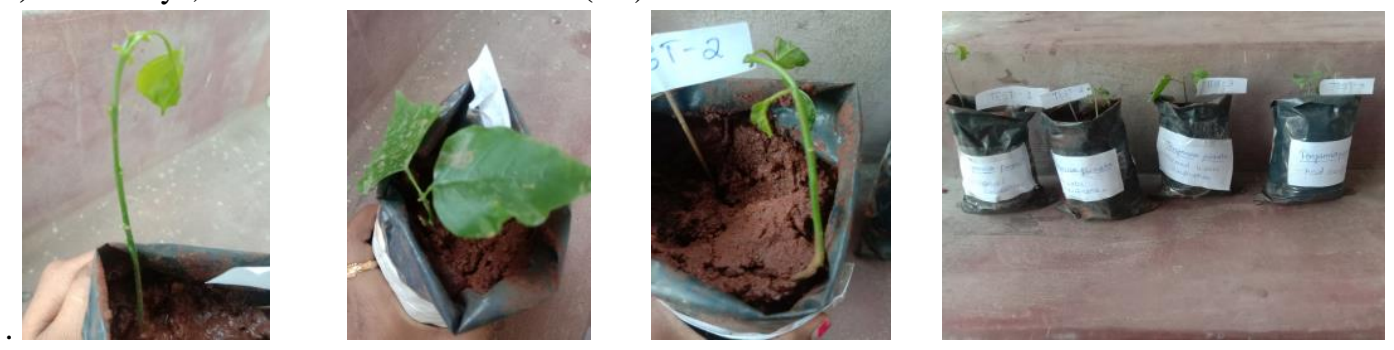

Tabulation:

\section{GERMINATION PERCENTAGE OF SEED:}

Germination percentage $\%=\mathrm{Ng} / \mathrm{Ns} \times 100$ where, $\mathrm{Ng}=$ number of seeds germinated, $\mathrm{Ns}=$ total number of seeds. 
Table: Germination percentage of seeds as influenced by different pretreatments

\begin{tabular}{|c|c|c|c|c|c|c|c|c|}
\hline \multirow[t]{2}{*}{$\begin{array}{ll}\text { NAME } & \text { OF } \\
\text { SEEDS } & \end{array}$} & \multirow[t]{2}{*}{$\begin{array}{l}\text { NAME OF } \\
\text { SCARIFICATION }\end{array}$} & \multirow{2}{*}{$\begin{array}{l}\text { TOTAL } \\
\text { NO OF } \\
\text { SEEDS }\end{array}$} & \multicolumn{3}{|c|}{ DAYS } & \multirow{2}{*}{$\begin{array}{l}\text { GERMINATI } \\
\text { ON } \\
\text { PERCENTAG } \\
\text { E\% }\end{array}$} & \multicolumn{2}{|c|}{$\begin{array}{l}\text { STANDARD } \\
\text { DEVIATION }\end{array}$} \\
\hline & & & $\begin{array}{l}0- \\
25\end{array}$ & $\begin{array}{l}25- \\
50\end{array}$ & $\begin{array}{l}50- \\
75\end{array}$ & & $\begin{array}{l}\text { SHOO } \\
\text { T } \\
\text { LENG } \\
\text { TH }\end{array}$ & $\begin{array}{l}\text { ROOT } \\
\text { LENGTH }\end{array}$ \\
\hline \multirow{4}{*}{$\begin{array}{l}\text { Terminalia } \\
\text { bellirica } \\
\text { (Gaertn.) Roxb. }\end{array}$} & Mechanical & 4 & - & 2 & 2 & $50 \%$ & $\begin{array}{l}7.36 \pm 3 . \\
15\end{array}$ & $3.28 \pm 0.79$ \\
\hline & Ricewater treatment & 4 & 1 & 3 & 3 & $75 \%$ & $\begin{array}{l}9.24 \pm 4 . \\
24\end{array}$ & $4.19 \pm 1.32$ \\
\hline & $\begin{array}{l}\text { Coconutwater } \\
\text { treatment }\end{array}$ & 4 & 2 & 3 & 3 & $75 \%$ & $\begin{array}{l}8.54 \pm 3 . \\
83\end{array}$ & $4.54 \pm 1.48$ \\
\hline & Acid treatment & 4 & 2 & 3 & 4 & $100 \%$ & $\begin{array}{l}10.36 \pm \\
4.88\end{array}$ & $5.24 \pm 1.88$ \\
\hline \multirow{4}{*}{$\begin{array}{l}\text { Terminalia } \\
\text { chebula } \\
\text { (Gaertn.) Retz. }\end{array}$} & Mechanical & 4 & - & 1 & 2 & $50 \%$ & $\begin{array}{l}6.66 \pm 1 . \\
97\end{array}$ & $3.22 \pm 0.04$ \\
\hline & Ricewater treatment & 4 & 2 & 3 & 4 & $100 \%$ & $\begin{array}{l}7.29 \pm 2 . \\
34\end{array}$ & $3.86 \pm 0.58$ \\
\hline & $\begin{array}{l}\text { Coconutwater } \\
\text { treatment }\end{array}$ & 4 & - & 1 & 2 & $50 \%$ & $\begin{array}{l}8.59 \pm 3 . \\
09\end{array}$ & $4.02 \pm 0.67$ \\
\hline & Acid treatment & 4 & 2 & 4 & 4 & $100 \%$ & $\begin{array}{l}9.32 \pm 3 \\
51\end{array}$ & $4.67 \pm 1.04$ \\
\hline \multirow[t]{4}{*}{$\begin{array}{l}\text { Tamarindus } \\
\text { indica } \mathrm{L} \text {. }\end{array}$} & Mechanial & 4 & 1 & 3 & 3 & $75 \%$ & $\begin{array}{l}9.87 \pm 3 . \\
83\end{array}$ & $4.45 \pm 0.70$ \\
\hline & Ricewater treatment & 4 & - & 2 & 2 & $50 \%$ & $\begin{array}{l}10.21 \pm \\
4.02\end{array}$ & $5.46 \pm 1.28$ \\
\hline & $\begin{array}{l}\text { Coconutwater } \\
\text { treatment }\end{array}$ & 4 & 2 & 2 & 3 & $75 \%$ & $\begin{array}{l}7.32 \pm 2 . \\
35\end{array}$ & $3.97 \pm 0.42$ \\
\hline & Acid treatment & 4 & 3 & 3 & 4 & $100 \%$ & $\begin{array}{l}12.17 \pm \\
5.15\end{array}$ & $6.78 \pm 2.04$ \\
\hline
\end{tabular}




\begin{tabular}{|c|c|c|c|c|c|c|c|c|}
\hline \multirow[t]{4}{*}{$\begin{array}{l}\text { Santalum } \\
\text { album } \mathrm{L} .\end{array}$} & Mechanical & 4 & - & - & 1 & $25 \%$ & $\begin{array}{l}5.16 \pm 1 . \\
79\end{array}$ & $\begin{array}{l}2.22 \pm \\
0.24\end{array}$ \\
\hline & Ricewater treatment & 4 & - & 1 & 2 & $50 \%$ & $\begin{array}{l}7.19 \pm 2 . \\
96\end{array}$ & $\begin{array}{l}3.53 \pm \\
0.87\end{array}$ \\
\hline & Coconutwater treatment & 4 & 2 & 2 & 3 & $75 \%$ & $\begin{array}{l}6.18 \pm 2 . \\
38\end{array}$ & $\begin{array}{l}3.18 \pm \\
0.67\end{array}$ \\
\hline & Acid treatment & 4 & 3 & 3 & 4 & $100 \%$ & $\begin{array}{l}8.14 \pm 3 . \\
50\end{array}$ & $\begin{array}{l}4.78 \pm \\
1.57\end{array}$ \\
\hline \multirow{4}{*}{$\begin{array}{l}\text { Pongamia } \\
\text { pinnata (L.) } \\
\text { Pierre }\end{array}$} & Mechanical & 4 & - & 3 & 3 & $75 \%$ & $\begin{array}{l}7.78 \pm 2 . \\
62\end{array}$ & $\begin{array}{l}3.98 \pm \\
0.43\end{array}$ \\
\hline & Ricewater treatment & 4 & 1 & 3 & 3 & $75 \%$ & $\begin{array}{l}10.45 \pm \\
4.16\end{array}$ & $\begin{array}{l}5.87 \pm \\
1.52\end{array}$ \\
\hline & Coconutwater treatment & 4 & 2 & 2 & 2 & $50 \%$ & $\begin{array}{l}8.54 \pm 3 . \\
06\end{array}$ & $\begin{array}{l}4.87 \pm \\
0.94\end{array}$ \\
\hline & Acid scarification & 4 & 2 & 4 & 4 & $100 \%$ & $\begin{array}{l}11.02 \pm \\
4.49\end{array}$ & $\begin{array}{l}6.02 \pm \\
1.60\end{array}$ \\
\hline
\end{tabular}

120

\section{DIFFERENT METHOD OF SCARIFICATION IN FIVE TYPES} OF SEEDS

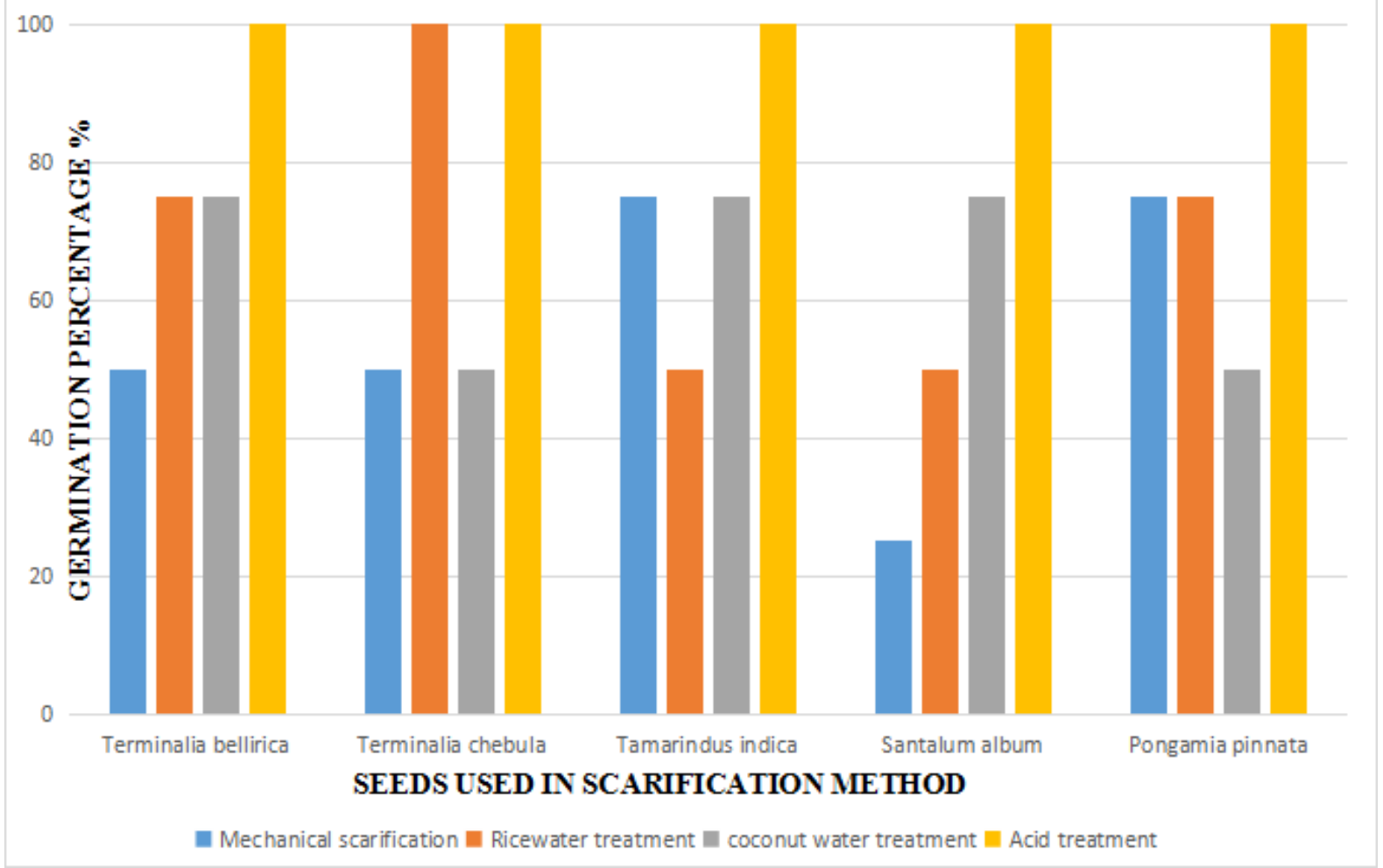

The highest germination percentage were observed in acid treatment(T4) in all five types of seeds. Sulphuric acid treatments were effective in softening and increase in permeability of the hard endocarp of seeds and increases the seed germination significantly. This treatment leads to easy penetration of water and activation of embryos. 
Coconut water $(\mathrm{CW})$ is the colorless liquid endosperm of green coconuts (Cocos nucifera) which its liquid endosperm contains a number of amino acids, organic acids, nucleic acids, several vitamins, sugars and sugar alcohols, plant hormones (auxins, cytokinins), minerals and other unidentified substances, none of which alone is totally responsible for promoting the growth of seeds in coconut water treatment (T3). Ricewater contains Triglycerides and lipids each make up 10 percent of the rice water composition is present at 9 percent. Carbohydrates, inositol, phytic acid and inorganic substances are other components in rice water. These helps to promote the growth of seeds in rice water treatment (T2).

\section{CONCLUSION}

The study material Terminalia chebula (Gaertn.) Retz., Terminalia bellirica (Gaertn.) Roxb., Pongamia pinnata (L.) Pierre , Santalum album L., Tamarindus indica L. seeds were collected from IFGTB, Coimbatore.The five types of seeds are pre-soaked in different treatment of scarification for different period of time. The result showed positive for most of the seeds germination. For establishing nursery of a particular species for producing maximum number of quality seedlings with minimum cost, time and labour, the seed pretreatments are required.Since the seed coat of Terminalia chebula (Gaertn.) Retz., Terminalia bellirica (Gaertn.) Roxb., Pongamia pinnata (L.) Pierre, Santalum album L., Tamarindus indica L. are hard, it takes more time to germinate with lower germination percentage in nursery establishment.the present study of pre-sowing treatments of seeds would prove itself potential in the practical fields. Among the treatments applied in the experiment for Terminalia chebula (Gaertn.) Retz., Terminalia bellirica (Gaertn.) Roxb., Pongamia pinnata (L.) Pierre, Santalum album L., acid treatment (10\% of con $\mathrm{H} 2 \mathrm{SO} 4)$ was found more effective in respect to faster germination, higher germination percentage, seedling growth compare to other treatment. Therefore, the different methods of scarification may be an important aspect of future study to avoid the difficulties of hard coat seeds for better germination.

\section{REFERENCES}

[1] Singh, U., Wadhwani, A. M. and Johir, B. M. 1965. Dictionary of Economic Plants in India. Indian Council of Agricultural Research, New Delhi, 288 p.

[2] Dutta, B. K., Rahman, I., \& Das, T. (1998). Antifungal activity of Indian plant extracts Antimyzetische Aktivitat indischer Pflanzenextrakte. Mycoses, 41(11/12), 535-536.
[3] Yukawa, T. A., Kurokawa, M., Sato, H., Yoshida, Y., Kageyama, S., Hasegawa, T., Namba, T., Imakita,M., Hozumi, T. and Shiraki, K.(1996). Prophylactic treatment of cytomegalovirus infection with traditional herbs. Antiviral research, 32(2), 63-70.

[4] Saleem, A., Husheem, M., Härkönen, P., \& Pihlaja, K. (2002). Inhibition of cancer cell growth by crude extract and the phenolics of Terminalia chebula retz. fruit. Journal of Ethnopharmacology, 81(3), 327-336.

[5] Shankar, U. (2001). A case of high tree diversity in a sal (Shorea robusta)-dominated lowland forest of Eastern Himalaya: Floristic composition, regeneration and conservation. Current Science, 776-786.

[6] Luna, R. K. (1996). Plantation Trees. Dehradun. International Book Distributors. 975p.

[7] CSIR. 1985. The Wealth of India. (A Dictionary of India Raw Material \& Industrial Products). Publication \& Information Directorate CSIR, New Delhi. Vol. I A.

[8] Todaria, N. P., \& Negim, A. K. (1992). Pretreatment of some Indian Cassia seeds to improve their germination. Seed science and technology, 20(3), 583-588.

[9] Bajpai, M., Pande, A., Tewari, S. K., \& Prakash, D. (2005). Phenolic contents and antioxidant activity of some food and medicinal plants. International journal of food sciences and nutrition, 56(4), 287-291.

[10] Shivanna, H., Balachandra, H. C., \& Suresh, N. L. (2010). Effect of pre-sowing treatment on germination of Terminalia bellerica (Ber). Karnataka Journal of Agricultural Sciences, 20(2).

[11] Kumar, R., Bohra, J. S., Kumava, N., \& Singh, A. K. (2015). Fodder yield, nutrient uptake and quality of baby corn (Zea mays L.) as influenced by NPKS and Zn fertilization. Research on Crops, 16(2).

[12] Kumar, R., Bohra, J. S., Singh, A. K., \& Kumawat, N. (2015). Productivity, profitability and nutrient-use efficiency of baby corn (Zea mays) as influenced of varying fertility levels. Indian J. Agron, 60(2), 285-290.

[13] Jain, S. H., Angandi, V. G., Shankaranarayana, K. H., \& Ravikumar, G. (2003). Relationship between girth and percentage of oil in sandal provenances. Sandalwood Research Newsletter, 18, 4-5.

[14] Shrinivasa, U. (2001). A viable substitute for diesel in rural India. Current Science, 80(12), 1483-1484.

[15] Tanaka, T., Iinuma, M., Yuki, K., Fujii, Y., \& Mizuno, M. (1992). Flavonoids in root bark of Pongamia pinnata. Phytochemistry, 31(3), 993-998.

[16] Wani, S. P., \& Sreedevi, T. K. (2005). Pongamia's journey from forest to micro-enterprise for improving livelihoods. Pongamia as a source of Biodiesel in India, 189.

[17] Meher, L. C., Dharmagadda, V. S., \& Naik, S. N. (2006). Optimization of alkali-catalyzed transesterification of Pongamia pinnata oil for production of biodiesel. Bioresource technology, 97(12), 1392-1397.

[18] Kuriakose, S. V., \& Prasad, M. N. V. (2008). Cadmium stress affects seed germination and seedling growth in Sorghum bicolor (L.) Moench by changing the activities of 
hydrolyzing enzymes. Plant growth regulation, 54(2), 143156.

[19] Silva, L. M. D. M., Aguiar, I. B. D., \& Rodrigues, T. D. J. (2001). Seed germination of Bowdichia virgilioides Kunth, under water stress. Revista Brasileira de Engenharia Agrícola e Ambiental, 5(1), 115-118.

[20] Mayer, A. M., \& Poljakoff-Mayber, A. (1963). The germination of seeds. The germination of seeds.

[21] Hadas A., (1976).Water uptake and germination of leguminous seeds under changing external water potential in osmoticum solution, Journal of Experimental Botany 27(98), 480-489.

[22] Gama-Arachchige, N. S., Baskin, J. M., Geneve, R. L., \& Baskin, C. C. (2013). Quantitative analysis of the thermal requirements for stepwise physical dormancy-break in seeds of the winter annual Geranium carolinianum (Geraniaceae). Annals of Botany, 111(5), 849-858..

[23] L. C. Nwoboshi,(1982). Tropical Silviculture: Principles and Techniques, Ibadan University Press. 